\title{
Lung function, biological monitoring, and biological effect monitoring of gemstone cutters exposed to beryls
}

Ralf Wegner, Regine Heinrich-Ramm, Dennis Nowak, Karin Olma, Bernd Poschadel, Dieter Szadkowski

\begin{abstract}
Objectives-Gemstone cutters are potentially exposed to various carcinogenic and fibrogenic metals such as chromium, nickel, aluminium, and beryllium, as well as to lead. Increased beryllium concentrations had been reported in the air of workplaces of beryl cutters in Idar-Oberstein, Germany. The aim of the survey was to study the excretion of beryllium in cutters and grinders with occupational exposure to beryls-for example, aquamarines and emeralds-to examine the prevalence of beryllium sensitisation with the beryllium lymphocyte transformation test (BeLT), to examine the prevalence of lung disease induced by beryllium, to describe the internal load of the respective metals relative to work process, and to screen for genotoxic effects in this particular profession.
\end{abstract}

Methods-In a cross sectional investigation, 57 out of 100 gemstone cutters working in 12 factories in Idar-Oberstein with occupational exposure to beryls underwent medical examinations, a chest radiograph, lung function testing (spirometry, airway resistance with the interrupter technique), and biological monitoring, including measurements of aluminium, chromium, and nickel in urine as well as lead in blood. Beryllium in urine was measured with a newly developed direct electrothermal atomic absorption spectroscopy technique with a measurement limit of $0.06 \mu \mathrm{g} / 1$. Also, cytogenetic tests (rates of micronuclei and sister chromatid exchange), and a BeLT were performed. Airborne concentrations of beryllium were measured in three factories. As no adequate local control group was available, the cutters were categorised into those with an exposure to beryls of $>4$ hours/week (group A) and $\leqslant 4$ hours/week (group B).

Results-Clinical, radiological, or spirometric abnormalities indicating pneumoconiosis were detected in none of the gemstone cutters. Metal concentrations in biological material were far below the respective biological limit values, and beryllium in urine was only measurable in subjects of group A. Cytogenetic investigations showed normal values which were independent of the duration of beryllium exposure. In one subject, the BeLT was positive. Beryllium stimulation indices were significantly higher in subjects with detectable beryllium in the urine than in those with beryllium concentrations below the detection limit $(p<0.05)$. In one factory, two out of four measurements of airborne beryllium concentrations were well above the German threshold limit value of $2 \mu \mathrm{g} / \mathrm{m}^{3}$ (twofold and 10-fold), and all gemstone cutters working in this factory had measurable beryllium concentrations in urine.

Conclusion-No adverse clinical health effects were found in this cross sectional investigation of gemstone cutters working with beryls. However, an improvement in workplace hygiene is recommended, accompanied by biological monitoring of beryllium in urine.

(Occup Environ Med 2000;57:133-139)

Keywords: gemstone cutter; beryllium in urine; lymphocyte transformation test

From the 15th century, Idar-Oberstein, Germany, has been a major European centre of the gemstone processing industry. Currently, the precious stones (no diamonds) handled are mostly from overseas-for example, South America and Africa (table 1). For the purpose of cutting and grinding corundums (rubies, sapphires) and beryls (emeralds and aquamarines), discs of corundum or microdiamonds cemented in nickel are used. Polishing is done with diamond powder or discs containing lead. Polishing discs containing cobalt, which are commonly used for diamond polishing, are not used in Idar-Oberstein.

It is generally thought that dusts from grinding beryls contain beryllium only as an insoluble silicatic complex, and so this element would not be bioavailable to the gemstone cutters. We are unaware of any study aiming at the detection of beryllium in the urine of gemstone cutters. Despite the rather low turnover of material containing beryllium during cutting

Table 1 Chemical structure of gemstones

\begin{tabular}{ll}
\hline $\begin{array}{l}\text { Beryls (aquamarine, } \\
\text { emerald) }\end{array}$ & $\mathrm{Al}_{2} \mathrm{Be}_{3}\left[\mathrm{Si}_{6} \mathrm{O}_{18}\right]$ \\
$\begin{array}{l}\text { Chrysoprases } \\
\text { Corundums (ruby, } \\
\text { sapphire) }\end{array}$ & $\mathrm{SiO}_{2}+\mathrm{Ni}$ \\
$\begin{array}{l}\text { Quartzes (agate, } \\
\text { amethyst) }\end{array}$ & $\mathrm{Al}_{2} \mathrm{O}_{3}+\mathrm{Cr}$ \\
$\begin{array}{l}\text { Tanzanites } \\
\text { Topaz }\end{array}$ & $\mathrm{SiO}_{2}$ \\
$\mathrm{Ca}_{2} \mathrm{Al}_{3}\left[\mathrm{O} / \mathrm{OH} / \mathrm{SiO}_{4} / \mathrm{SiO}_{7}\right]+\mathrm{V}$ \\
Tourmalines & $\mathrm{Al}_{2}\left[\mathrm{SiO} /(\mathrm{OH}, \mathrm{F})_{2}\right]$ \\
\hline & $\mathrm{Na}, \mathrm{Li}, \mathrm{Al}, \mathrm{Mg}, \mathrm{Fe}, \mathrm{Mn}, \mathrm{Ca}, \mathrm{BO}_{3}, \mathrm{Si}_{6} \mathrm{O}_{18}$ \\
\hline
\end{tabular}


and polishing precious stones, increased beryllium concentrations have been reported in the air at the workplaces of beryl cutters in Idar-Oberstein. Therefore, we wondered whether this finding could be reflected by positive biomonitoring of the urine of exposed subjects, with a new modified technique. Furthermore, despite the limitations of a cross sectional design, we intended to study whether diseases associated with beryllium, particularly berylliosis, as has been shown to occur in workers involved in ceramic manufacturing, ${ }^{1}$ space and atomic engineering, ${ }^{2}$ and in dental laboratory technicians ${ }^{3}$ would be found in gemstone cutters. Also, we wanted to find the prevalence of beryllium sensitisation with the beryllium lymphocyte transformation test (BeLT). Furthermore, beryllium and its compounds are considered to be carcinogenic at least in laboratory animals. ${ }^{45}$ In a cohort mortality study on patients with beryllium disease, Steenland and Ward ${ }^{6}$ and Ward et al reported an increased lung cancer mortality ratio particularly among those subjects with a history of acute disease. MacMahon, ${ }^{8}$ however, argued that uncontrolled confounding by cigarette smoking was a more likely explanation of the excess lung cancer than occupational exposure to beryllium compounds. Nevertheless, the International Agency for Research on Cancer (IARC) classified beryllium and its compounds as carcinogenic in humans (group 1).

As well as to beryllium, gemstone cutters are potentially exposed to other metals - such as chromium, nickel, aluminium, and lead. This is partly due to the naturally occurring metal content of precious stones, but also to the use of abrasives and grinding discs. Exposure to chromium as well as to nickel may induce both occupational asthma ${ }^{910}$ and lung cancer in humans. ${ }^{11-15}$ Due to the extremely low concentrations of chromium in corundums, exposure during cutting and polishing these gemstones is probably negligible. Exposure to aluminium, which is present in rubies and sapphires as well as in abrasives may, in principle, cause an interstitial lung disease, aluminosis. ${ }^{16-19}$ Furthermore, occupational exposure to lead has to be considered in gemstone cutters because of the use of polishing discs containing lead. When working on quartzes, quartz may become airborne. However, respirable quartz concentrations (alveolar fraction of aerosol in breathing zone) had always been $<0.15 \mathrm{mg} / \mathrm{m}^{3}$ (former German MAK concentration) during cutting or grinding gemstones (as opposed to larger pieces of quartz-for example, statues), so that no measurable risk of silicosis is assumed. When diamond polishing discs are used, nickel concentrations in the air had not been detectable or were below $0.5 \mathrm{mg} / \mathrm{m}^{3}$ (German TRK concentration, inhalable fraction of aerosol in breathing zone).

Therefore, it was the aim of our survey to study the excretion of beryllium in grinders, to examine the prevalence of beryllium sensitisation with the BeLT, to examine the prevalence of lung disease induced by beryllium, to describe the internal load of potentially or proved carcinogenic metals relative to work process and to screen for genotoxic effects by testing the rates of micronuclei and sister chromatid exchange in a group of gemstone cutters.

\section{Methods}

SUBJECTS

In Idar-Oberstein and surrounding villages, about 2000 people are involved in cutting and polishing gemstones. Out of these, about $40 \%$ work with coloured stones, the rest mainly with quartzes. In Idar-Oberstein, no diamonds are processed. According to the estimations of the German Industrial Professional Assosiation, about 200 workers cut or polish beryls, but are also involved in cutting other precious and semiprecious stones. Work is done in small workshops with a mean number of about six highly specialised employees. Traditionally, the turnover of workers is very low. The scattered nature of this industry and the different times spent by the workers working with beryls make such an epidemiological survey particularly difficult and may explain the problems in recruitment to the study population.

Our study focused on 12 representative workshops specialising in the processing of beryls. Altogether 100 workers were invited to participate, and 57 agreed (46 men, 11 women; 27 non-smokers, 17 former smokers, and 13 current smokers, table 2).

Due to legal restrictions on transferring personal data in Germany, demographic data of the 43 non-responders could not be found. But it is unlikely that responders differed from non-responders systematically. Participation rates varied between $50 \%$ and $100 \%$ in the different workshops. Local control subjects without any exposure to gemstone dust were not available. Therefore the participants were classified as working often ( $>4$ hours/week, exposed group $\mathrm{A}, \mathrm{n}=27$, mean (SD) 21.1 (12.5) hours/week) or less often ( $\leqslant 4$ hours/week, internal control group $\mathrm{B}, \mathrm{n}=30$, mean (SD) 0.7 (1.2) hours/week) with beryls. Standardised questionnaires were administered, and clinical examination was performed. The study was performed in April and June 1995.

\section{CHEST RADIOGRAPHS}

Posterioanterior chest films $(n=56)$ were obtained unless they had been taken during the previous 6 months. All radiographs were classified according to the International Labor Organisation system for pneumoconiosis (ILO, 1980) independently by two experienced readers without knowledge of the subjects classification to the group A or B.

\section{LUNG FUNCTION TESTING}

In all subjects, spirometry was performed, and airway resistance $\left(R_{\text {occ }}\right)$ was measured by the interrupter technique (Flowscreen 2.1, Jaeger, Würzburg, Germany). All measurements were performed by the same technician and with identical equipment, as suggested by Quanjer et $a l^{20}$ Before measurements in every single subject the pneumotachograph was volume calibrated. For inspiratory vital capacity (slowly performed IVC), forced expiratory volume in 1 second $\left(\mathrm{FEV}_{1}\right)$, forced vital capacity 
(FVC), peak expiratory flow (PEF), and maximal expiratory flows $\left(\mathrm{MEF}_{50}, \mathrm{MEF}_{25}, \mathrm{MEF}_{25-75}\right)$ the best values were taken from at least three acceptable and reproducible manoeuvres and compared with reference values. ${ }^{20}$ For airway resistance with the interrupter technique $\left(\mathrm{R}_{\mathrm{occ}}\right)$, we calculated the mean of 15 measurements and used the regression equation of Zwick and Schenz. ${ }^{21}$

BIOMONITORING OF METALS

Subjects were instructed to collect urine from before the shift in the morning, after showering, in specially cleaned (by rinsing with nitric acid $1 \mathrm{~mol} / 1$ and ultrapure water) polyethylene tubes wrapped in sealed plastic bags to avoid contamination. Urine was collected between 1400 and 1530 after the shift at the workplace, and blood was drawn after the shift. Material was transported to our laboratory overnight by courier. Cytogenetic and beryllium lymphocyte transformation tests were performed 15 to 17 hours after specimens had been collected, and metals were analysed within 8 weeks (storage was at $-18^{\circ} \mathrm{C}$ ). Concentrations of chromium, nickel, and aluminium in urine as well as lead concentrations in blood were measured according to published standard methods. ${ }^{22}$ Limits of measurement for chromium, nickel, and aluminium in urine were $0.6,0.2$, and $1.0 \mu \mathrm{g} / 1$, respectively.

Beryllium in urine was measured with a newly developed direct electrothermal atomic absorption spectrometry (AAS) procedure. Urine was diluted with nitric acid (0.05 $\mathrm{mmol} / 1,500 \mu \mathrm{l}$ urine, plus $1075 \mu \mathrm{l}$ nitric acid), applying standard addition for calibration. Mineralisation and atomisation temperatures of the pyrolytically coated graphite tube were optimised with urine specimens of occupationally exposed subjects (atomic absorption spectrometer Spectra AA 800, Varian, Mulgrave, Victoria, Australia). At the applied mineralisation temperature of $1350^{\circ} \mathrm{C}$, non-specific absorption was below 0.02 units and could be easily compensated through the Zeeman background correction method. Under these conditions and with an atomisation temperature of $2450^{\circ} \mathrm{C}$, no relevant loss of beryllium occurred, as shown by a nearly unchanged level of absorption specific to beryllium. As no reagent blanks could be found, the limit of measurement was calculated to be $0.06 \mu \mathrm{g} / 1$ by the mean slope of the standard addition lines derived from 34 urine specimens of nonexposed subjects (mean (SD) age 38 (12) years). Imprecision within the series $(n=11$; mean $0.75 \mu \mathrm{g} / \mathrm{l})$ and between days $(\mathrm{n}=11$; mean $0.36 \mu \mathrm{g} / \mathrm{l}$ ) amounted to $6.3 \%$ and $10.9 \%$, respectively. Recovery experiments performed at mean concentrations of 0.41 and $0.75 \mu \mathrm{g} / 1$ yielded recovery rates of 95.6 and $90.3 \%$. Also, accuracy was confirmed by analysing commercially available control material (Seronorm batch 9024 ) corresponding to $109 \%$ of the recommended value and $98 \%$ of the added amount.

\section{CYTOGENETIC TESTS}

Cytogenetic tests performed in 51 subjects included analyses of rates of micronuclei and sister chromatid exchange. The lymphocyte micronucleus assay was performed with a modified cytokinesis block method. ${ }^{23}{ }^{24}$ Briefly, lymphocytes were cultured for 72 hours, and cytochalasin B was added after 44 hours of incubation. After washing, fixing, and harvesting the cells onto slides, they were dried and stained with 4',6-diamino-2-phenylindole (DAPI, $5 \mathrm{mg} / \mathrm{l}$; Serva, Heidelberg, Germany). Two thousand binucleated cells per sample were scored blindly by the same reader.

Rates of sister chromatid exchange were assessed as described. ${ }^{25}{ }^{26}$ Whole blood cultures were established in chromosome medium containing 5-bromo-2-deoxyuridine for 72 hours. Colcemid $(0.1 \mu \mathrm{g} / \mathrm{ml})$ was added to each culture 2 hours before the end of incubation.

Table 2 Mean (SD) and median values of variables under study for all subjects and subjects (group $A$ ) with $>4$ h/week $v<4$ h/week exposure to beryls (group B), and results of $t$ tests $\left({ }^{*} p<0.05\right)$, differences in means $(95 \%$ CI)

\begin{tabular}{|c|c|c|c|c|c|c|c|c|c|c|c|c|}
\hline \multirow[b]{3}{*}{ Variable } & & & & \multicolumn{6}{|c|}{ Exposure to beryls } & \multirow[b]{3}{*}{$t$ Value } & \multirow[b]{3}{*}{ Difference } & \multirow[b]{3}{*}{$95 \% C I$} \\
\hline & \multicolumn{3}{|c|}{ All subjects $(n=57)$} & \multicolumn{3}{|c|}{$A>4$ h/week $(n=27)$} & \multicolumn{3}{|c|}{$B \leqslant 4$ h/week $(n=30)$} & & & \\
\hline & Mean & $S D$ & Median & Mean & $S D$ & Median & Mean & $S D$ & Median & & & \\
\hline Age $(y)$ & 42.0 & 13.3 & 42.0 & 42.3 & 14.0 & 44.0 & 41.6 & 12.9 & 41.0 & 0.20 & 0.7 & -4.2 to 5.6 \\
\hline Duration of work as jeweller (y) & 24.8 & 15.4 & 23.0 & 25.5 & 15.8 & 30.0 & 24.2 & 15.2 & 20.0 & 0.33 & 1.3 & -4.5 to 7.1 \\
\hline $\begin{array}{l}\text { Duration of work per week } \\
(\mathrm{h} / \text { week })\end{array}$ & 38.5 & 6.6 & 40.0 & 39.2 & 5.9 & 40.0 & 37.9 & 7.3 & 39.0 & 0.77 & 1.3 & -1.2 to 3.8 \\
\hline $\begin{array}{l}\text { Nickel (before the shift) ( } \mu \mathrm{g} / 1 \\
\text { urine) }\end{array}$ & 1.48 & 1.01 & 1.25 & 1.41 & 1.07 & 1.10 & 1.55 & 0.96 & 1.60 & 0.52 & -0.14 & -0.52 to 2.4 \\
\hline Nickel (after the shift) ( $\mu \mathrm{g} / \mathrm{l}$ urine) & 1.11 & 0.73 & 1.10 & 1.04 & 0.72 & 0.90 & 1.18 & 0.75 & 1.15 & 0.73 & -0.14 & -0.42 to 0.14 \\
\hline $\begin{array}{l}\text { Aluminium (before the shift) }(\mu \mathrm{g} / 1 \\
\text { urine) }\end{array}$ & 7.90 & 11.8 & 5.40 & 7.31 & 5.30 & 5.90 & 8.43 & 15.6 & 4.75 & 0.35 & -1.12 & -5.44 to 3.2 \\
\hline $\begin{array}{l}\text { Alumimium (after the shift) ( } \mu \mathrm{g} / 1 \\
\text { urine) } \\
\text { Bervllium (before the shift) }(\mu \mathrm{g} / \mathrm{l}\end{array}$ & 6.34 & 10.1 & 3.90 & 5.64 & 4.70 & 4.50 & 6.98 & 13.3 & 3.35 & 0.49 & -1.34 & -5.08 to 2.4 \\
\hline $\begin{array}{l}\text { Beryllium (before the shift) }(\mu \mathrm{g} / 1 \\
\text { urine) } \\
\text { Beryllium (after the shift) ( } \mu \mathrm{g} / 1\end{array}$ & - & - & - & 0.13 & 0.12 & 0.09 & nd & - & - & - & - & - \\
\hline $\begin{array}{l}\text { urine) } \\
\text { Relative density, urine (before the }\end{array}$ & - & - & - & 0.08 & 0.07 & 0.03 & nd & - & - & - & - & - \\
\hline $\begin{array}{l}\text { shift) } \\
\text { Relative density, urine (after the }\end{array}$ & 1.022 & 0.006 & 1.020 & 1.022 & 0.005 & 1.022 & 1.021 & 0.007 & 1.020 & 0.45 & -0.001 & -0.003 to 0.001 \\
\hline shift) & 1.019 & 0.007 & 1.019 & 1.020 & 0.007 & 1.021 & 1.019 & 0.007 & 1.019 & 0.46 & -0.001 & -0.004 to 0.002 \\
\hline Lead (after the shift) ( $\mu \mathrm{g} / 1$ blood) & 86.2 & 46.8 & 69.4 & 99.6 & 54.4 & 91.2 & 74.2 & 35.6 & 66.2 & $2.10^{\star}$ & 25.4 & 8.2 to 42.6 \\
\hline Micronucleus rate $(/ 500$ cells $)$ & 9.93 & 4.34 & 9.74 & 9.81 & 4.89 & 8.67 & 10.0 & 3.87 & 9.91 & 0.19 & -0.19 & -1.85 to 1.47 \\
\hline SCE rate (/cell) & 9.82 & 1.78 & 9.48 & 9.70 & 1.11 & 9.87 & 9.91 & 2.17 & 9.38 & 0.42 & -0.21 & -0.86 to 0.44 \\
\hline
\end{tabular}

nd=Not detectable; $\mathrm{SCE}=$ sister chromotid exchange. 
Lymphocytes were washed, harvested onto slides, and air dried chromosome preparations were made. Slides were stained with Giemsa and scored blindly by the same reader. Fifteen well differentiated diploid second division metaphases with at least 40 chromosomes were scored in each subject.

BERYLLIUM LYMPHOCYTE TRANSFORMATION TEST The blood beryllium lymphocyte transformation test (BeLT) is an in vitro measure of the specific immune response of cells to beryllium antigen. It can serve as a valuable aid in the differential diagnosis of granulomatous lung diseases in people exposed to beryllium. ${ }^{27}$ The response to beryllium is understood to play a central part in the immunopathogenesis of chronic beryllium disease. ${ }^{28}$ The BeLT was performed according to a modification of the photometric method described by Wemme et al. ${ }^{29}$ Briefly, lymphocytes were cultured for 96 hours together with beryllium sulphate at concentrations of $1 \times 10^{-4}, 1 \times 10^{-5}$, and $1 \times 10^{-6}$ $\mathrm{mmol} / \mathrm{l}$, or phytohaemagglutinin alone. After 72 hours of culture, 5-bromo-2-deoxyuridine (BrdU) was added. At the end of the incubation period, the microtitre plate was centrifuged and supernatants were discarded. Cells were fixed and dried, followed by denaturation with $\mathrm{HCl}$. Cells were incubated with antibody to bromodeoxyuridine solution for 60 minutes, then incubated with polyclonal rabbit antibody to mouse IgG conjugated to peroxidase for another 60 minutes. Chromogenous $o$-phenylenediamine dihydrochloride solution was added, and the developed plates were read at $490 \mathrm{~nm}$ in a Dynatech reader (Dynatech Laboratories, Denkendorf, Germany). The BeLT was performed in 54 gemstone cutters; specimens of 30 additional people without any contact to beryllium served as controls (18 men, 12 women; mean (SD) age 45 (11) years).

DEFINITION OF ABNORMAL BELT

The highest stimulation value of the three beryllium concentrations was divided by the stimulation value performed with BrdU only. The upper limit based on the mean peak stimulation index (SI) +2 SDs (1.61) for unexposed subjects (controls). The SIs higher than this value were considered to be increased.

Table 3 Mean (SD) values of lung function variables under study for all subjects and subjects (group $A$ ) with $>4$ h/week $v \leqslant 4$ h/week exposure to beryls (group $B$ ), and results of multiple analysis of variance ( $F_{1}=$ exposure group, $F_{2}=$ non-smokers, former smokers, and current smokers; $F_{3}=$ interaction)

\begin{tabular}{|c|c|c|c|c|c|c|c|c|c|}
\hline \multirow{3}{*}{$\begin{array}{l}\text { Variable } \\
\text { (\% predicted) }\end{array}$} & & & \multicolumn{4}{|c|}{ Exposure to beryls } & \multirow[b]{3}{*}{$F_{1}$} & \multirow[b]{3}{*}{$F_{2}$} & \multirow[b]{3}{*}{$F_{3}$} \\
\hline & \multicolumn{2}{|c|}{$\begin{array}{l}\text { All subjects } \\
(n=57)\end{array}$} & \multicolumn{2}{|c|}{$\begin{array}{l}A>4 h / \text { week } \\
(n=27)\end{array}$} & \multicolumn{2}{|c|}{$\begin{array}{l}B \leqslant 4 \text { h/week } \\
(n=30)\end{array}$} & & & \\
\hline & Mean & $S D$ & Mean & $S D$ & Mean & $S D$ & & & \\
\hline IVC & 101.5 & 13.5 & 103.3 & 12.7 & 99.9 & 14.2 & 0.319 & 0.122 & 0.776 \\
\hline FVC & 106.1 & 13.4 & 106.8 & 14.1 & 105.4 & 12.9 & 0.123 & 0.490 & 0.881 \\
\hline $\mathrm{FEV}_{1}$ & 104.8 & 15.4 & 107.2 & 17.3 & 102.5 & 13.4 & 0.915 & 1.759 & 1.223 \\
\hline $\mathrm{FEV}_{1} / \mathrm{IVC}$ & 100.7 & 9.6 & 101.6 & 10.0 & 99.9 & 9.2 & 0.301 & 1.904 & 0.654 \\
\hline PEF & 109.7 & 21.5 & 109.9 & 20.2 & 109.5 & 22.9 & 0.230 & 1.605 & 0.535 \\
\hline $\mathrm{MEF}_{50}$ & 93.5 & 33.4 & 96.4 & 37.1 & 91.0 & 30.2 & 0.442 & 1.606 & 0.403 \\
\hline $\mathrm{MEF}_{25}$ & 85.0 & 35.4 & 90.3 & 36.7 & 80.2 & 34.2 & 2.046 & $3.186^{\star}$ & 0.100 \\
\hline $\mathrm{MEF}_{25-75}$ & 93.5 & 31.8 & 96.9 & 33.7 & 90.6 & 30.3 & 0.712 & 2.318 & 0.417 \\
\hline Rocc & 95.8 & 25.4 & 93.1 & 28.6 & 98.2 & 22.5 & 0.604 & 0.397 & 0.267 \\
\hline
\end{tabular}

$\star$ :p<0.05; Tukey test: non-smokers $v$ current smokers.
PERSONAL MONITORING OF AIRBORNE BERYLLIUM In eight gemstone cutters working in three typical factories, airborne beryllium concentration was measured over 2 hour sampling periods with personal samplers (DuPontpump $\alpha 1$, sampling system GSP, $37 \mathrm{~mm}$ membrane filter; pore size $0.8 \mu \mathrm{m}$, flow rate 3.5 $1 / \mathrm{min})$. Beryllium content was measured by AAS.

EVALUATION OF DATA

Mean (SD) values and medians were calculated for age, duration of exposure, lung function, results of biomonitoring, and cytogenetic investigations. Values below the detection limits were entered as half of the detection limit. Two tailed $t$ test statistics for independent or dependent samples were applied, and the differences in means between groups $\mathrm{A}$ and $\mathrm{B}$ were calculated with their $95 \%$ confidence intervals (95\% CIs). Lung function data were further analysed with multiple analysis of variance and Tukey tests with the independent variables exposure groups A or B and smoking (non-smokers, former smokers, current smokers). Also, non-parametric tests were carried out (Spearmans R, correlation between the beryllium concentration in urine and the individual stimulation index of BeLT). All tests were done at $\alpha=0.05$ significance level.

\section{Results}

Subjects' characteristics, exposure data, biomonitoring data, and results of cytogenetic tests are summarised in table 2, which also contains data stratified according to the duration of work with beryls (group A >4 hours/week, and B $\leqslant 4$ hours/week), lung function values are presented in table 3 . Subjects with high and low exposure to beryls differed in exposure to other gemstones: apart from work with beryls, gemstone cutters of group A often had contact with tanzanites (mean (SD) 9.4 (12.0) hours/week), and tourmalines (4.7 (5.4)). Subjects of group B worked mostly on quartzes (9.6 (11.2) hours/week), corundums (9.6 (15.4)), tourmalines (6.7 (7.9)), and tanzanites $(6.0(9.7))$. Twenty one $(37 \%)$ subjects complained of respiratory symptoms (blocked nose $21 \%$, cough $9 \%$, NS between groups A and B). No clinical abnormalities suggestive of interstitial lung disease were detected in any subjects.

\section{CHEST RADIOGRAPHS}

One male subject of group A (age 53 years) showed bihilar enlargement of lymph nodes and micronodular disseminated opacities (ILO 1980, pq 1/1, all fields, hi). His medical records included a diagnosis of sarcoidosis based on a chest $x$ ray film and high resolution CT. He declined follow up investigation. In a further six employees, pleural or parenchymal abnormalities were detected compatible with patients' histories of tuberculosis or pneumonia. Normal chest radiographic findings were obtained in 49 subjects. 
LUNG FUNCTION

Three out of the 57 gemstone cutters showed slight decreases of inspiratory vital capacity (IVC $<80 \%$ of predicted, minimum $72 \%$ ), which might show the beginning of restrictive lung function. Two of these three cutters had no contact with beryls, one cutter had 5 hours/ week. In the patient with a history of pulmonary sarcoidosis, no lung function abnormality was detected. No significant differences in lung function were found between employees of exposure groups A and B (table 3), even after adjustment for smoking.

BIOMONITORING OF METALS

Chromium in urine was detectable only in five and three samples before and after the shift, respectively. Nickel and aluminium in urine were measurable in 52 and 55 urine samples before and 50 and 47 urine samples after the shift, respectively, with mean (SD) concentrations given in table 2 . In none of the subjects were the German biological limit values (BAT, EKA) for aluminium, chromium, or nickel (200, 20, and $45 \mu \mathrm{g} / \mathrm{l})$ exceeded. Mean aluminium excretion in urine did not differ according to the use of corundum either as a precious stone or as an abrasive, with mean (SD) values of 8.5 (13.0) $\mu \mathrm{g} / \mathrm{l}$ before and 5.4 (5.0) $\mu \mathrm{g} / \mathrm{l}$ after the shift in subjects exposed to corundums $\leqslant 4$ hours/week $(n=46)$ compared with $5.2(2.9) \mu \mathrm{g} / 1$ before and $10.5(20.9) \mu \mathrm{g} / 1$ after the shift in subjects exposed $>4$ hours/ week $(n=11)$.

Of group A, 17 out of the 27 subjects had in at least one, out of two, samples of urinary beryllium concentrations above the detection limit (17 before and 12 after the shift). By contrast, none of the urine samples from subjects in group B contained measurable beryllium concentrations. Mean concentrations of beryllium in urine of group A subjects before and after the shift were not significantly different. None of the gemstone cutters who had possibly slightly restrictive lung function had beryllium in measurable concentrations in urine.

Mean (SD) blood lead concentrations are also presented in table 2. In subjects who reported the use of polishing discs containing lead, mean (SD) blood concentration was $104.8(54.7) \mu \mathrm{g} / 1$ and was therefore higher $(\mathrm{p}<0.05)$ than in subjects with a negative history of lead (74.6 (37.4) $\mu \mathrm{g} / \mathrm{l})$. Work with beryls was reported for longer periods in the subjects who reported the use of polishing discs containing lead (mean (SD), 15.2 (15.4) hours/week) than in the group without exposure to lead (7.2 (11.1) hours/week, p<0.05). The highest blood lead concentration was 233 $\mu \mathrm{g} / 1$ and therefore below the current German BAT concentration $(700 \mu \mathrm{g} / \mathrm{l})$.

CYTOGENETIC TESTS

Mean rates of micronuclei and sister chromatid exchange showed no significant differences between subgroups of employees with high or low exposure to beryllium (table 2). The same was true after stratification for smoking: mean (SD) counts of micronuclei in smokers and non-smokers with low exposure to beryls was
9.4 (3.4) and 10.3 (4.1) compared with 8.7 (1.9) and 10.0 (5.2)/500 cells in smokers and non-smokers with high exposure. Mean (SD) rates of sister chromatid exchange in smokers and non-smokers with low exposure to beryls were 11.6 (2.2) and $9.3(1.8) v 10.5(0.7)$ and 9.6 (1.1) per cell in smokers and non-smokers with high exposure. No effect of smoking on rates of micronucli could be found. In smokers, however, mean (SD) rates of sister chromatid exchange were 11.3 (1.9) per cell and therefore significantly $(\mathrm{p}<0.01)$ higher than in nonsmokers (mean (SD) 9.4 (1.5)).

BERYLLIUM LYMPHOCYTE TRANSFORMATION TEST In one subject, the BeLT turned out positive. His age was 61 , his exposure time to beryls 25 hours/week, and he had been working in his profession for 47 years. Beryllium in urine was detectable at concentrations of 0.33 and 0.09 $\mu \mathrm{g} / \mathrm{l}$ (before and after the shift). His chest radiograph was normal, and lung function within the lower range (VC $82 \%$ predicted, $\mathrm{FEV}_{1} 78 \%$ predicted). The subject with the diagnosis of sarcoidosis showed a stimulation index within the normal range. Stimulation indices were slightly but significantly higher in cutters with detectable beryllium concentrations in the urine $(>0.06 \mu \mathrm{g} / \mathrm{l})$ than in subjects with concentrations below the detectable concentration (mean (SD) $1.17(0.26)$ v 1.04 $(0.15), \mathrm{p}<0.05)$. There was also a significant correlation between the (maximal individual) beryllium excretion in urine and the individual beryllium stimulation index (Spearman's $\mathrm{R}$ for the whole group $0.287, \mathrm{p}<0.05)$.

PERSONAL MONITORING OF AIRBORNE BERYLLIUM, CORRESPONDING VALUES OF BERYLLIUM IN URINE Results of ambient monitoring ranged from $<0.4 \mu \mathrm{g} / \mathrm{m}^{3}$ to $20.0 \mu \mathrm{g} / \mathrm{m}^{3}$. The highest value was found during the cutting of aquamarines. In factory 1 , two of four measurements $(20,4$, 1 , and $1 \mu \mathrm{g} / \mathrm{m}^{3}$ ) showed airborne beryllium concentrations above the German ambient threshold limit value (TRK) of $2 \mu \mathrm{g} / \mathrm{m}^{3}$. In factory 2 data were below the detection limit, factory 3 showed ambient beryllium concentrations of 2 and $1 \mu \mathrm{g} / \mathrm{m}^{3}$. In 15 of 18 specimens (nine before, and six after the shift) of the corresponding employees in factory $1(n=9)$ beryllium was detectable in urine (before 0.18 $(0.15) \mu \mathrm{g} / \mathrm{l}$, and after the shift $0.12(0.10) \mu \mathrm{g} / \mathrm{l}$, difference NS). Beryllium in urine exceeded the detection limit in none of the other employees (factories 2 and 3, $\mathrm{n}=14$ ).

\section{Discussion}

This study, the first in the German precious stone industry, was initiated to verify a potential health hazard in beryl grinders. Our aim was twofold: firstly, we wanted to detect whether exposed gemstone cutters incorporate beryllium, and secondly, whether diseases associated with beryllium are present in this group.

The particular problems of such a study are due to the scattered nature of this industry and the difficulty in recruiting a sufficient number of exposed workers. Out of 100 cutters, 57 
were willing to undergo the whole procedure including $x$ ray film and blood tests. In the study of Nemery et $a b^{\beta 0}$ among Belgian diamond polishers, no such tests were done, and the response rate was $78 \%$. As no adequate local control group was available, we decided to categorise cutters into those with an exposure of $>4$ hours/week (group A) and $\leqslant 4$ hours/ week (group B). This arbitrarily chosen cut off turned out to be reasonable as beryllium was detectable in 29 of the 54 urine samples of group A subjects but in none of the workers in group B.

Facing the difficulties in recruiting many workshops, of course, a healthy workshop effect has to be considered which may bias our results towards underestimation of potentially adverse health effects. However, in one of the factories in which we were able to recruit nine subjects (thus making up one third of group A) airborne beryllium concentration was up to 10 -fold over the German technical limit value, which argues against particularly healthy workshops being grossly overrepresented. Also, we are unable to exclude bias caused by mostly healthy workers agreeing to participate. Due to legal restrictions in the availability of nonparticipants' data and those who had left their jobs, we cannot measure the potential size of the problem.

Within these limitations, in this cross sectional study we detected no clinically adverse health effects attributable to occupational exposure, except for one subject with a positive beryllium lymphocyte transformation test. More than $50 \%$ of the specimens from gemstone cutters with frequent contact with beryls ( $>4$ hours/week, group A, including all subjects of one factory) showed beryllium concentrations above the detection limit of 0.06 $\mu \mathrm{g} / 1$ urine. By contrast, as already mentioned, none of the urine samples collected from subjects exposed $\leqslant 4$ hours/week contained measurable beryllium concentrations. So the urine test of beryllium was highly specific to (but less sensitive in) the exposed category as defined in this study. Thus, by contrast with what has been generally thought, our findings show that beryllium aerosolised during gemstone cutting is bioavailable in principle.

To the best of our knowledge, no comparable studies on the effect of metal exposure or measures of health outcome in cutters of coloured gemstone have been published in recent years. Nemery et $a l^{30}$ found decreased pulmonary function in diamond polishers with exposure to cobalt. The cobalt originated from the grinding surface of polishing discs made of microdiamonds cemented with cobalt. Lung or pleural diseases induced by asbestos have been reported in jewellers who used asbestos insulation material for soldering, ${ }^{3132}$ and increased mortality in jewellers due to pancreatic cancer has also been reported by Sparks and Wegman, ${ }^{33}$ although not confirmed. ${ }^{34}$ In polishers $^{33}$ and female jewellery workers, ${ }^{34}$ significant excess mortalities due to gastric cancer were reported. Respiratory cancer was found less often than expected in either cohort.
In our group of gemstone cutters, we were particularly interested in exposure to beryllium and potentially related health effects of beryllium. For the purpose of this study, a direct electrothermal AAS procedure had been developed with a detection limit eightfold lower than that published previously $(0.5 \mu \mathrm{g} / \mathrm{l}) .^{22}$ Thus, beryllium values in urine $>0.06 \mu \mathrm{g} / 1$ could now be interpreted as causally related to occupational exposure as all 30 of the subjects with a low degree of occupational exposure had beryllium concentrations in urine below that figure.

Data about rates of micronuclei and sister chromatid exchange did not reflect genotoxic effects differing between groups. In the cytokinesis block method used for the micronucleus test, ${ }^{23}$ blastogenesis of $\mathrm{T}$ lymphocytes provided a means of assessing cytogenetic effects mainly due to long term exposure, as $\mathrm{T}$ cells have a half life in the range of years. Also, the frequency of sister chromatid exchange in lymphocytes did not differ between workers with high and low exposure (table 2), which was also true after stratification for smoking. However we found a significant effect of smoking on rates of sister chromatid exchange, which is compatible with the findings of other authors. $^{35-37}$

The biological exposure data of chromium, nickel, and aluminium did not show a measurable health risk due to potentially carcinogenic, asthmatogenic, or fibrogenic metals and their compounds in this group of gemstone cutters. Mean blood lead concentration of workers who used polishing discs containing lead, most of them belonging to the exposure group A, exeeded the 95th percentile of our reference value derived from occupationally nonexposed subjects $(100 \mu \mathrm{g} / \mathrm{l}),{ }^{38}$ and thus showed a work related incorporation of lead, albeit far below current German BAT concentration $(700 \mu \mathrm{g} / \mathrm{l})$.

Spirometric and radiological findings were without abnormalities that could be related to occupational exposure, especially against beryllium. Owing to the cross sectional design of the study, however, we cannot rule out potential adverse health effects in subjects who left their job before our investigation. One patient, however, with a history of sarcoidosis and a chest $x$ ray film compatible both with a diagnosis of sarcoidosis and berylliosis, declined a follow up investigation which might have included a transbronchial biopsy and a BeLT with lymphocytes derived from bronchoalveolar lavage fluid. ${ }^{39}{ }^{40}$ On the other hand, berylliosis is highly unlikely in this patient in view of his negative BeLT.

In one subject we found a positive BeLT, but both chest $x$ ray film and lung function were normal. As beryllium was detectable in his urine before and after the shift and given the high specificity of a positive BeLT, this finding may be a marker of latent, preclinical disease, ${ }^{41}$ thus warranting clinical follow up.

The principal mechanism of berylliosis is not due to toxicity, but is immunologically mediated. Therefore, low exposure may occasionally also cause sensitisation in susceptible subjects 
(genetically). Yoshida $e t a l^{42}$ showed that the $\mathrm{T}$ cells of workers continuously exposed to beryllium $>0.01 \mu \mathrm{g} / \mathrm{m}^{3}$ could be activated and that the cell mediated immune response of workers could be promoted. Our result that beryllium stimulation indices were significantly higher in cutters with detectable beryllium in urine than in the others, and the significant correlation between the individual beryllium content in urine and the individual stimulation index (BeLT), may be a sign of strain in gemstone cutters with exposure to beryllium (dose-response relation) and indicates probably the sensitising potency of beryllium.

In conclusion, grinding and cutting of gemstones containing beryllium may lead to airborne beryllium concentrations above current threshold limit values, and incorporation of beryllium could be shown in most subjects working $>4$ hours/week with beryls. Considering a positive BeLT in one subject and significantly higher beryllium stimulation indices in cutters with detectable beryllium concentrations in urine, we suggest improvements in workplace ventilation accompanied by routinely performed beryllium measurements in urine.

We acknowledge the local support of Professor Bank, Idar-Oberstein for classification of jewels and contact with the jewellers; the excellent technical support of Mrs Finger, Koops, and Nern in our institute; and the laboratory advice about the BeLT given by Professor Müller-Quernheim, Forschungszentrum Borstel; Dr Wagenmann, Idar-Oberstein, kindly performed the chest radiographs; and Mrs Böckler and Mr Nieuwenhuizen, Berufsgenossenschaft der Feinmechanik und Nieuwenhuizen, Böln provids data oirborne beryllium, und . This work was support conBentration at selected workplaces. This work was supported by Köln.

1 Kreiss K, Wasserman S, Mroz MM, et al. Beryllium disease screening in the ceramics industry. 7 Occup Med screening in the

2 Williams WJ. Beryllium disease. In: Parkes WR, ed. Occupational lung disorders. Oxford: Butterworth/Heinemann, 1994;571-92

3 Kotloff RM, Richman PS, Greenacre JK, et al. Chronic beryllium disease in a dental laboratory technician. Am Rev beryllium disease in a dental la

4 Groth DH. Carcinogenicity of beryllium: review of the literature, Environ Res 1980;21:56-62

5 International Agency for Research on Cancer. Some metals and metallic compounds. IARC Monogr Eval Carcinog Risk Hum 1980;23:143-204.

6 Steenland K, Ward E. Lung cancer incidence among patients with beryllium disease: a cohort mortality study. $\mathscr{F}$ Natl Cancer Inst 1991:83:1380-5.

7 Ward E, Okun A, Ruder A, et al. A mortality study of workers at seven beryllium processing plants. $A m \mathcal{F}$ Ind $\mathrm{Med}$ 1992;22:885-904

8 MacMahon B. The epidemiological evidence on the carcinogenicity of beryllium in humans. $\mathcal{F}$ Occup Med 1994; 36:15-24.

9 Cirla AM, Bernabeo F, Orroboni JF, et al. In: Brown SS, Sunderman FW Jr, eds. Progress in nickel toxicology. Oxford: Blackwell, 1985;165-72.

10 Nemery B. Metal toxicity and the respiratory tract. Eur Respir f 1990;3:202-19.

11 Doll R, Morgan LG, Speizer FE. Cancers in the lung and nasal sinuses in nickel workers. Br f Cancer 1970;24:62332.

12 Turhan U, Wollburg C, Angerer J, et al. Der Nickelgehalt menschlicher Lungen und seine Bedeutung für die Beurteilung berufsbedingter Bronchialkarzinome. Arbeitsmed Sozialmed Präventivmed 1985;20:277-81.

13 Raithel HJ. Nickel und seine Verbindungen: Arbeitsmedizinisch-toxikologische Aspekte, Teil B: Kanzerogenität: Arbeitsschutz. Arbeitsmed Sozialmed Präventivmed 1987;22:301-10.
14 Langard S. One hundred years of chromium and cancer: a review of epidemiological evidence and selected case review of epidemiological evidence and
reports. Am f Ind Med 1990;17:189-215.

15 Lees PSJ. Chromium and disease: review of epidemiologic studies with particular reference to etiologic information provided by measures of exposure. Environ Health Perspect 1991;92:93-104.

16 Shaver CG, Ridell AR. Lung changes associated with the manufacture of aluminia abrasives. F Ind Hyg Toxicol 1947; 29:145-57.

17 Chen WR, Monnat RJ jr, Chen M, et al. Aluminium induced pulmonary granulomatosis. Hum Pathol 1978;9:705-11.

18 De Vuyst P, Dumortier P, Schandene L, et al. Sarcoid-like lung granulomatosis induced by aluminium dusts. Am Rev Respir Dis 1987;135:493-7.

19 Gilks B, Churg A. Aluminium-induced pulmonary fibrosis: do fibers play a part? Am Rev Respir Dis 1987;136:176-9.

20 Quanjer $\mathrm{PhH}$, Tammeling GJ, Cotes JE, et al. Lung volumes and forced ventilatory flows. Eur Respir f 1993;6 (suppl 16):5-40.

21 Zwick H, Schenz G. Referenzwerte für die Atemwiderstandsmessung mit der Ganzverschlußtechnik. Atemw: Lungenkrkh, 1989;15:127-32.

22 Angerer J, Schaller KH. Analytische Methoden zur Prüfung gesundheitsschädlicher Arbeitsstoffe; Analysen im biologischen Material. Weinheim: Verlag Chemie, 1976-1994.

23 Fenech $M$. The cytokinesis-block micronucleus assay in nucleated cells. Prog Clin Biol Res 1990;340:195-206.

$24 \mathrm{Holz}$ O, Scherer G, Brodtmeier S, et al. Determination of low level exposure to volatile aromatic hydrocarbons and genotoxic effects in workers at a styrene plant. Occup Environ Med 1995;52:420-8.

25 Perry P, Wolff S. Differential Giemsa staining of sister chromatids and the study of sister chromatid exchange without autoradiography. Chromosoma 1974;48:341-53.

26 Jagdt B, Warncke K, Auer H, et al. Sleep deprivation does not induce sister chromatid exchange in humans. Mutat Res 1996;361:11-15.

27 Bargon J, Kronenberger H, Bergman NL, et al. Lymphocyte transformation test in a group of foundry workers exposed to beryllium and non-exposed controls. Eur $\mathcal{F}$ Respir Dis Suppl 1986;146:211-15.

28 Newman LS. Significance of the blood beryllium lymphocyte proliferation test. Environ Health Perspect 1996; 104(suppl 5):953-6.

29 Wemme H, Pfeiffer S, Heck R, et al. Measurement of lymphocyte proliferation: critical analysis of radioactive and photometric measures. Immunobiology 1992;185:7889.

30 Nemery B, Casier P, Roosels D, et al. Survey of cobalt exposure and respiratory health in diamond polishers. Am Rev Respir Dis 1992;145:610-16.

31 Kern DG, Hanley KT, Roggli VL. Malignant mesothelioma in the jewelry industry. Am F Ind Med 1993;21:409-16.

32 Dossing M, Langer SM. Asbestos-induced lung injury among Danish jewelry workers. Am f Ind Med 1994;26: $755-8$.

33 Sparks PJ, Wegman D. Cause of death among jewelry workers. F Occup Med 1980;22:733-6.

34 Hayes RB, Dosemeci M, Riscigno M, et al. Cancer mortality among jewelry workers. Am f Ind Med 1993;24:743-51.

35 Bender MA, Preston RJ, Leonard RC, et al. Chromosomal aberrations and sister-chromatid exchanges in peripheral blood lymphocytes of a large human population sample. Mutat Res 1988;204:421-33.

36 Soper KA, Stolley PD, Galloway SM, et al. Sisterchromatid-exchange (SCE) report on control subjects in study of occupationally exposed workers. Mutat Res 1984; 129:77-88.

37 Jelmert O, Hansteen LL, Langard S. Enhanced cytogenetic detection of previous in vivo exposure to mutagens in human lymphocytes after treatment with inhibitors of DNA synthesis and DNA repair in vitro. Mutat Res 1992;271:289-98.

38 Heinrich-Ramm R, Wegner R, Mindt-Prüfert S, et al. Reference values for selected metals in body fluids of male employees in northern Germany. Metal Ions in Biology and Medicine 1998;5:753-7.

39 Rossman MD, Kern JA, Elias JA, et al. Proliferative response of bronchoalveolar lymphocytes to beryllium. Ann Intern Med 1988;108:687-93.

40 Saltini C, Weinstock K, Kirby M, et al. Maintenance of alveolitis in chronic beryllium disease by beryllium-specific helper T cells. N Engl f Med 1989;320:1103-9.

41 Newman LS, Kreiss K, King TE, et al. Pathologic and immunologic alterations in early stages of beryllium disease. Am Rev Respir Dis 1989;139:1479-86.

42 Yoshida T, Shima S, Nagaoka K, et al. Study on the beryllium lymphocyte transformation test and the beryllium levels in working environment. Ind Health 1997:35: 374-9. 